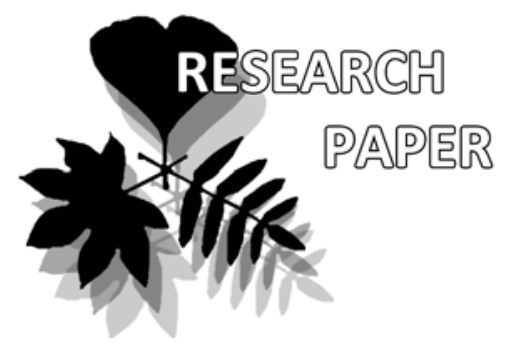

\title{
Contrasting Floristic Richness of Alpine Plant Communities on the Eastern Qinghai-Tibetan Plateau
}

Vladimir G. Onipchenko ${ }^{* 1,2}$, Alexander A. Shulakov ${ }^{1,2}$, Alexander S. Zernov ${ }^{1}$, Tatiana G. Elumeeva ${ }^{1}$, Yan Wu ${ }^{3}$, Qian Wang ${ }^{3}$, Marinus J.A.Werger ${ }^{4}$

Vladimir G. Onipchenko $* 1,2$

e-mail: vonipchenko@mail.ru

Alexander A. Shulakov ${ }^{1,2}$

e-mail:malaxis@yandex.ru

Alexander S. Zernov ${ }^{1}$

e-mail: zernov72@yandex.ru

Tatiana G. Elumeeva ${ }^{1}$

e-mail: dianthus@yandex.ru

Yan $\mathrm{Wu}^{3}$

e-mail: wuyan@cib.ac.cn

Qian Wang ${ }^{3}$

e-mail: wangqian@cib.ac.cn

Marinus J.A.Werger ${ }^{4}$

e-mail: M.J.A.Werger@uu.nl

${ }^{1}$ Moscow State Lomonosov University, 119991 Moscow, Russia

${ }^{2}$ Karachaevo-Cherkessian University,

Karachaevsk, Karachaevo-Cherkessian Republic, Russia

${ }^{3}$ Chengdu Institute of Biology CAS, Chengdu, China

${ }^{4}$ Utrecht University, Utrecht,

The Netherlands

* corresponding author

Manuscript received: 17.11.2013

Review completed: 08.01.2014

Accepted for publication: 14.02.2014

\begin{abstract}
A B S T R A C T
We expected that local plant species richness is high in relatively old and large territories that harbor specific conditions with characteristic communities. Furthermore, herbivory can promote the coexistence of different species and support high floristic richness. We tested the hypothesis that large alpine areas with a long history of grazing in the Tibetian Mountains support high local floristic richness in comparison with other regions. Number of vascular plant taxa was recorded in series of nested quadrates with sides from 5 to $1000 \mathrm{~cm}$ in four alpine communities with different grazing regimes in the eastern part of the Qinghai-Tibetan plateau at Mount Kaka, Minshan Mountains, Sichuan province, China. We obtained high values for vascular species numbers for moderately grazed Tibetan meadows and Spiraea thickets (75.4 and 81.0 species $/ 100 \mathrm{~m}^{2}$, respectively). This supports our hypothesis. On the other hand, alpine fens and Rhododendron thickets scored relatively poor on floristic richness values, and this may result mainly from the marginal ecological environment and also from the competitive advantage of Rhododendron in the absence of grazing.
\end{abstract}

\section{Keywords}

species-area relationship, Kobresia alpine meadow, alpine fen, Rhododendron thicket, species diversity, grazing regime

\section{P E 3 Ю M E}

Онипченко В.Г., Шулаков А.А., Зернов А.С., Елумеева Т.Г., У Я., Ванг Ч., Вергер М.Аж.А. Контрастное фмористическое богатство аАьпийских раститемьных сообществ на восточном Цинхай-Тибетском пиато

Мы предположили, что мокальная флористическая насыщенность наиболее высока на относительно обширных и старых территориях, вмещающих типичные растительные сообщества в своеобразных условиях. Фитофаги также могут способствовать сосуществованию и подлерживать флористическое разнообразие. Эти гипотезы были проверены на примере альпийских сообществ, занимающих обширные площади в Тибете. Исследовали число виАов сосудистых растений на вмещающих сериях кваАратов размером от 5 х 5 см до 10 х 10 м в сообществах четырех типов с различным режимом выпаса на востоке Цинхай-Тибетского плато в провинции Сычуань, КНР. Мы получили высокие величины флористической насыщенности Аля умеренно выпасаемых кобрезиевых мугов и кустарниковых сообществ с Аоминированием Spiraea spp. (75.4 и 81.0 вил/100 м², соответственно). С другой стороны, альпийские болота и заросли рододенАронов характеризовались относительно низкими величинами флористической насыщенности, что может быть связано со специфическими экологическими условиями в первом случае и конкуренцией со стороны видов Rhododendron при отсутствии выпаса во втором.

\section{Ключевы е слова}

кривая виды-площадь, альпийские кобрезиевые куга, альпийское болото, заросли рододендрона, видовое разнообразие, выпас

\section{INTRODUCTION}

Floristic richness (number of species per unit area) depends on several factors, which can be categorized into two groups. One combines current ecological factors, such as grazing regime, soil fertility, disturbance, microclimate, etc. The other may be called historical and involves such parameters as general floristic richness of a region, floro- genetics, migrations, climatic and geological history, etc. (Zobel 1992, Onipchenko \& Semenova 1995, Tang et al. 2013).

According to classical biogeography floristic richness on islands is lower than in areas of the same size on the mainland (MacArthur \& Wilson 1967). We confirmed that rule when comparing alpine communities in the Alps, the Caucasus 
and New Zealand: those in New Zealand were significantly poorer in species than those in the Alps and the Caucasus (Onipchenko \& Semenova 1995, Onipchenko et al. 2005). On the other hand, local floristic richness depends on the size of the total area covered by a specific community (Laanisto et al. 2008, Onipchenko \& Pavlov 2009). Also floristic richness increases with the age of a community (its time of existence) (Miles 1979, Grubb 1986, Ouborg 1993). Accordingly, local plant species richness is expected to be high in relatively old and large territories that harbor specific conditions in which the community occurs. As such, the alpine plant communities on the Tibetan Mountains may be considered good examples, because they occur over extended areas and their habitats have a rather high geological age.

On the other hand, the effects of herbivores, both specialized and generalist grazers, under moderate grazing, can promote the coexistence of different species and support high floristic richness as a result of trampling and because of opening up the denser layers of the vegetation (Grime 1979, 2001, Willems 1983, Shmida \& Ellner 1984, Tilman 1986, Jutila 1997, etc.).

The Tibetan Mountains represent an area of ancient grazing by wild and domestics yaks. Thus, we expect high local floristic richness values for the alpine Tibetan plant communities. The aim of our study was to check this hypothesis and compare neighboring communities within large and old alpine territories. In this study we therefore compare: 1) the floristic richness of vascular plant species in four alpine communities with different structure and yak grazing activity in Songpan County (in the eastern part of the Qinghai-Tibetan plateau); 2) the floristic richness of these Tibetan alpine communities with those of ecologically comparable communities throughout the world.

\section{MATERIALS AND METHODS}

\section{Site description}

The study area in the eastern part of the QinghaiTibetan plateau (further referred to as 'Tibet') is located at Mount Kaka (N 32 $\left.2^{\circ} 9^{\prime}, \mathrm{E} 103^{\circ} 41^{\prime}\right)$, which is part of the Minshan Mountains and lies $40 \mathrm{~km}$ northwest of Songpan County, Sichuan province, China. The timberline is at about $3800 \mathrm{~m}$ a.s.l. and the alpine belt consists of alpine meadows and shrublands.

The climate of this area typically experiences Pacific Ocean monsoon from the east mixed with cold and dry wind currents typical of the inland plateau; it is classified as cold summers with dry winters (Peel et al. 2007). The annual mean temperature is $2.8^{\circ} \mathrm{C}$ with a mean value of $-7.6^{\circ} \mathrm{C}$ for January and $9.7^{\circ} \mathrm{C}$ for July. There is no absolutely frost-free season. The mean annual precipitation is $718 \mathrm{~mm}, 72 \%$ of which falls from June to August. Snow cover in the study site usually ranges from 0 to $0.4 \mathrm{~m}$ (Yan \& Onipchenko 2006). Soils mostly are silty loam inceptisols with a $\mathrm{pH}$ of 5.54-5.94 and SOM values of 41.5-60.0 g kg-1 dry soil.

We studied 4 adjacent plant communities:

1) Kobresia alpine meadows (KAM). These communities occupy gentle southern slopes and ridges. The most abundant herbaceous species are Sibbaldia procumbens, Anaphalis nepalensis, Gentiana hexaphylla, Trollius farreri, Festuca ovina, Ptilagrostis concinna, Kobresia kansuensis and K. humilis. Shrubs, such as Potentilla fruticosa, Caragana jubata and Spiraea alpina, cover 5-10\%. These Kobresia alpine meadows are mainly used as pastures. We studied these pastures at elevation between 3950 and $3960 \mathrm{~m}$ a.s.l.

2) Spiraea thickets (ST) occupy steeper southern slopes. Here, shrub cover exceeds $50 \%$. Floristic composition of these communities is similar to that of the Kobresia alpine meadows, but Sibbaldia procumbens is less abundant. The most frequent species are Deschampsia caespitosa, Poa versicolor, Caltha scaposa, Kobresia humilis, Saussurea salicifolia and Aconitum pendulum. Yaks here also nibble on Spiraea alpina shrubs, but to a lesser extent then in the Kobresia alpine meadows. The plots we studied were located at 3945-3955 m a.s.l.

3) Rhododendron thickets (RT) with Rhododendron przewalskii, $R$. phaeochrysum and $R$. zheguense occupy steep northern slopes. Moss cover (Hylocomium splendens, Sanionia uncinata, Ditrichum flexicaule, Dicranum spp.) reaches 30-40\%; vascular plants cover usually does not exceed 15-20\%. The most common species are Festuca ovina and Polygonum viviparum. Yaks avoid these steep slopes and consequently this community remains almost ungrazed. We studied plots at elevation 3950-3965 m a.s.l.

4) Alpine fens (AF) occupy smooth sites at flat ridges and at the lower parts of slopes. Mosses cover about $35 \%$. The most abundant vascular plants are Carex atrofuscoides, C. atrofusca subsp. minor, C. moorcroftii, Kobresia humilis, Polygonum macrophyllum, Pedicularis longiflora, Cremanthodium lineare and Caltha scaposa.. As the Kobresia alpine meadows, alpine fens are under intensive grazing.

\section{Field methods}

A series of sample plots, based on the design of Onipchenko \& Semenova (1995), were selected for each of the four communities at sites considered representative of the particular vegetation zone and with relatively uniform topography over an area sufficiently homogeneous to accommodate full samples. Each series consisted of nested quadrates

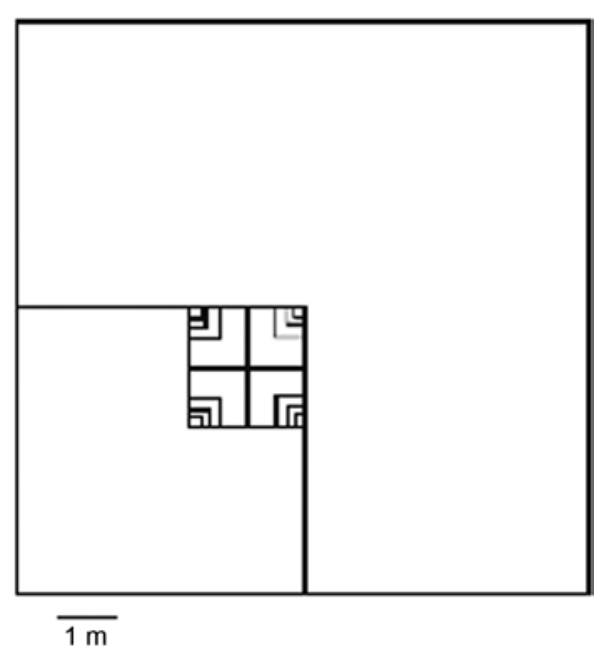

Figure 1 Sampling design with plots from 0.0025 to $100 \mathrm{~m}^{2}$ (from Onipchenko \& Semenova 1995) 
(Fig. 1) with sides of $5,10,25,50,100 \mathrm{~cm}$ (four replicates each), 200, 500 and $1000 \mathrm{~cm}$ (one replicate each). Five series were examined in each community type which thus provided five replicates for larger $\left(4,25\right.$ and $\left.100 \mathrm{~m}^{2}\right)$ plots and 20 for each of the smaller ones (total studied area $20000 \mathrm{~m}^{2}$ ). Only the number of vascular plant taxa was recorded.

\section{Data analysis}

Floristic richness (mean number of vascular species per plot, plus standard errors) was calculated for all eight plot sizes in each of the four communities. Two models, Arrenhius's (1921) power function (1) and Gleason's (1922) exponential model (2), were fitted by regressions as follows:

$$
\begin{aligned}
& S=c \times \cdot A^{z} \\
& S=a+b \times \ln A
\end{aligned}
$$

where $S=$ number of species in area $A ; a, b, c, z$ are regression parameters; coefficients " $c$ " and " $a$ " of equations (1) and (2) show the number of species per unit area $\left(\mathrm{m}^{2}\right)$; coefficients " $z$ " and " $b$ " show the rates at which species richness increases with area.

\section{RES U LTS}

The studied communities differ strongly in vascular plant floristic richness, as well as in the regression parameters of the models used to describe the increase of richness with increase of area (Table 1). Intensively grazed Kobresia meadows and Spiraea thickets (KAM and ST) have a very high floristic richness with values of $75.4 \pm 2.4$ (mean \pm SE) and $81.0 \pm 3.8$ vascular plant species per $100 \mathrm{~m}^{2}$, respectively. Maximal values for these communities were 82 and 95 species per $100 \mathrm{~m}^{2}$. Floristic richness per $1 \mathrm{~m}^{2}$ was also considerable for these communities ( 40 and 30 species, respectively).

On the other hand intensively grazed fens (AF) and practically non-grazed Rhododendron thickets (RT) score relatively low species richness values with $34.8 \pm 2.2$ and $26.8 \pm 1.4$ species per $100 \mathrm{~m}^{2}, 15$ and 11 species per $1 \mathrm{~m}^{2}$, respectively. All four communities also have different rates of increasing richness with area; $z$ values ranged from about 0.22 to 0.33 .

In 3 communities (KAM, ST, RT) Gleason's exponential model better fits our data than Arrenhius's power function, but the opposite is true for AF. In the less rich communities RT and AF the rate of increasing richness with area ( $b$ in Gleason's model) was low compared to that for the KAM and ST communities.

\section{DISCUSSION}

Our results show that the neighboring communities that we studied differ conspicuously in floristic richness: two communities are very rich and two are poor in species. The mean number of vascular plant species per $100 \mathrm{~m}^{2}$ in Kobresia alpine meadows and Spiraea thickets is about three time less than the absolute world maximum (233 species) recorded once for the same plot size in a Costa Rican tropical rain forest (Whithemore et al. 1985, Wilson et al. 2012). But the mean number of species, even in tropical lowland forest (in French Guiana), is about 80 species per $100 \mathrm{~m}^{2}$, which is close to the values we found for our KAM and ST communities (Bordenave et al. 1998). Higher floristic richness for small plots (15.5-19.7 species per $0.01 \mathrm{~m}^{2}$ ) was noted for Tibetian alpine meadow by Chen et al. (2008). Mean floristic richness values for mediterranean-type biodiversity hotspots (African fynbos, Australian heaths, Californian scrub, Mediterranean maquis) is $30-60$ species per $100 \mathrm{~m}^{2}$ (Keeley \& Fotheringham 2003). These values are lower than our data for the Tibetan KAM and ST alpine meadows and thickets. European dry grasslands and open coastal communities often also are floristically rich (with up to 140 species per $100 \mathrm{~m}^{2}$ including bryophytes and lichens), but vascular plants form about $1 / 3$ of their floristic richness (Dengler $\&$ Boch 2008, Dolnik \& Breuer 2008).

The single highest species richness for $1 \mathrm{~m}^{2}$ recorded so far in montane (not alpine!) grassland in Argentina is 89 species, but mean values for these communities were much lower: 19-37 species per $1 \mathrm{~m}^{2}$ (Cantero et al. 1999). Among alpine plant communities the highest plant biodiversity values were obtained for grasslands in the White Carpathian Mountains (median 81-107 species per $100 \mathrm{~m}^{2}$ and 38-49 per $1 \mathrm{~m}^{2}$ ) (Merunková et al. 2012), but the authors sampled subjectively selected plots with a high floristic richness. According to our knowledge the floristic richness of the Tibetan KAM and ST communities hold the second place among studied alpine communities.

Another important result of our study is the contrast in richness values between our communities. Rhododendron thickets (RT) and alpine fens (AF) are 2.5- to 3-fold poorer in floristic richness than neighboring KAM and ST communities. There are several explanations for this phenomenon. AF occurs on water-saturated peat soils, a condition that limits the potential number of species growing in that habitat. Similarly, lower species richness values were also shown for alpine fens in the Alps and the Caucasus in contrast with other adjacent communities in those regions (Onipchenko \& Semenova 1995). Moreover, alpine fens occupy less area than the other studied Tibetan communities and thus their floristic pool is smaller. A positive linear relation between floristic richness in small plots and total area covered by communities was shown for herbaceous alpine communities in the North-West Caucasus (Onipchenko \& Pavlov 2009). In comparison with the Alps and the Caucasus, Tibetan fens are richer in vascular plants (mean vascular plant species richness was 23, 23 and 35 species per $100 \mathrm{~m}^{2}$ respectively). This may be due to 1 ) the greater alpine species pool in the huge Tibetan area, 2) the rather intensive (but not extreme) yak grazing in the studied communities, 3) the more favorable environment in Tibet (with a longer growth season, higher temperatures, etc.) in comparison with the other mountains. For communities studied by us the first explanation (large area with a large species pool) does not seem to be important, since much larger fens occur in floodplains in the same region (Tsuyuzaki et al. 1990) and they have lower species numbers $\left(3-10\right.$ species per $1 \mathrm{~m}^{2}$ in comparison with about 15 species in our study).

The lowest floristic richness in our study was noted for Rhododendron thickets $\left(26.8\right.$ species per $100 \mathrm{~m}^{2}$ ). This value is much lower than data obtained for alpine Rhododendron 
Table 1. Floristic richness of vascular plants in four adjacent, contrasting alpine plant communities in different sized plots on Mount Kaka, Minshan Mountains, Sichuan province. Abbreviations: N - number of samples, KAM - Kobresia alpine meadows, ST - Spiraea thickets, RT - Rhododendron thickets, AF - Alpine fens

\begin{tabular}{|c|c|c|c|c|c|}
\hline \multirow{2}{*}{ Plot area, $\mathbf{m}^{2}$} & \multirow{2}{*}{$\mathbf{N}$} & \multicolumn{4}{|c|}{ mean floristic richness (species per plot) and standard errors } \\
\hline & & KAM & ST & RT & AF \\
\hline 0.0025 & 20 & $5.2 \pm 0.4$ & $3.2 \pm 0.4$ & $0.7 \pm 0.2$ & $3.0 \pm 0.2$ \\
\hline 0.01 & 20 & $11.0 \pm 0.7$ & $6.6 \pm 0.6$ & $1.9 \pm 0.3$ & $5.6 \pm 0.3$ \\
\hline 0.0625 & 20 & $21.2 \pm 0.8$ & $13.4 \pm 0.6$ & $5.1 \pm 0.4$ & $8.9 \pm 0.6$ \\
\hline 0.25 & 20 & $31.2 \pm 0.7$ & $21.4 \pm 0.9$ & $7.5 \pm 0.6$ & $11.9 \pm 0.8$ \\
\hline 1 & 20 & $39.9 \pm 0.7$ & $30.4 \pm 1.0$ & $10.6 \pm 0.6$ & $14.7 \pm 1.0$ \\
\hline 4 & 5 & $56.2 \pm 2.6$ & $50.8 \pm 2.4$ & $15.0 \pm 1.4$ & $21.6 \pm 1.6$ \\
\hline 25 & 5 & $67.2 \pm 2.3$ & $64.8 \pm 5.5$ & $21.2 \pm 1.3$ & $27.7 \pm 1.9$ \\
\hline 100 & 5 & $75.4 \pm 2.4$ & $81.0 \pm 3.8$ & $26.8 \pm 1.4$ & $34.8 \pm 2.2$ \\
\hline \multicolumn{6}{|l|}{$S=c \times A^{z}$} \\
\hline$c$ & & 33.65 & 26.66 & 8.45 & 14.33 \\
\hline$z$ & & 0.244 & 0.303 & 0.328 & 0.219 \\
\hline$r^{2}$ & & 0.905 & 0.940 & 0.941 & 0.981 \\
\hline \multicolumn{6}{|c|}{$S=a+b \times \ln A$} \\
\hline$a$ & & 43.22 & 39.13 & 12.79 & 17.94 \\
\hline$b$ & & 6.962 & 7.518 & 2.459 & 2.911 \\
\hline$r^{2}$ & & 0.989 & 0.948 & 0.959 & 0.958 \\
\hline
\end{tabular}

caucasicum scrub communities in the Caucasus (40.4 species) and Rhododendron ferrugineum shrubland in the Swiss Alps (39.2 species) (Onipchenko \& Semenova 1995). Thus, in this case neither a greater species pool nor a larger total area of Rhododendron thickets in the Tibetan Mountains are reflected in the floristic richness value of this community. We suggest that the main cause for the low floristic richness lies in the practical absence of grazing (disturbance) providing a strong competitive effect of the tall (1-2 m) dominant Rhododendron species over the herbaceous plants. Asymmetric competition for light (Connolly \& Wayne 1996, Schwinning \& Weiner 1998) may lead floristic richness to decrease.

Comparing our results with similar studies of alpine communities worldwide, they confirm several known biogeographical regularities. Generally, it is valid that the larger an alpine area, the higher its floristic richness. Alpine communities in the South Island of New Zealand are poorer in vascular plant species, for example low-alpine snow tussock-shrublands contain $20.8 \pm 2.0$ species per $100 \mathrm{~m}^{2}$ (Onipchenko et al. 2005), and the highest floristic richness in New Zealand (34 species per $100 \mathrm{~m}^{2}$ ) is noted for lowland shrublands and forests (Wilson \& Sykes 1988). Alpine communities of Central North Asia (Altay, Russia) and Northeast Asia (Priokhot'e) usually have 15-20 vascular plant species (highest value 40) per $100 \mathrm{~m}^{2}$ (Sedelnikov 1979, Shlotgauer 1990), and thus are floristically poorer than Tibetan ones, probably due to their northern location causing a colder climate in those mountains.

A moderate disturbance regime (grazing, mowing) is very important for a high floristic richness of plant communities (Willems 1983, Grime 2001). Mown wooded meadows in Estonia contain about 51 species per $4 \mathrm{~m}^{2}$ (Pärtel et al. 1999) which is close to our values for grazed Kobresia alpine meadows and Spiraea thickets.

\section{CONCLUSION}

We obtained high values for vascular species numbers for moderately grazed Tibetan meadows and Spiraea thickets (75.4 and 81.0 species per $100 \mathrm{~m}^{2}$, respectively) which seem to result from the added effects of the total floristic richness of the Tibetan Mountains, the widespread distribution of these communities and moderate yak grazing. On the other hand, alpine fens and Rhododendron tickets are relatively poor in floristic richness which may result from the critical ecological environment and also from the overwhelming competitive advantage of Rhododendron in the absence of grazing.

\section{LITERATURE CITED}

Arrhenius, O. 1921. Species and area. Journal of Ecology 9: 95-99.

Bordenave, B.G. \& J.-J. de Granville, M. Hoff 1998. Measurement of species richness of vascular plants in a neotropical rain forest in French Guiana. In: Forest Biodiversity in North, Central and South America, and the Caribbean. Man and Biosphere Series 21 (F. Dallmeier \& J.A. Comiskey, eds), p. 411-425. Paris.

Cantero, J.J., M. Pärtel \& M. Zobel 1999. Is species richness dependent on the neighboring stands? An analysis of the community patterns in mountain grasslands of Central Argentina. Oikos 87: 346-354.

Chen, J., Y. Yamamura, Y. Hori, M. Shiyomi, T. Yasuda, H. Zhou, Y. Li \& Y. Tang 2008. Small-scale species richness and its spatial variation in an alpine meadowon the Qinghai-Tibet Plateau. Ecological Research 23: 657-663.

Connolly, J. \& P. Wayne 1996. Asymmetric competition between plant species. Oecologia 108: 311-320.

Dengler, J. \& S. Boch 2008. Sampling-design effects on properties of species-area relationships - a case study from Estonian dry grassland communities. Folia Geobotanica 43: 289-304.

Dolnik, C. \& M. Breuer 2008. Scale dependency in the speciesarea relationship of plant communities. Folia Geobotanica 43: 305-318.

Gleason, H.A. 1922. On the relation between species and area. Ecology 3: 158-162. 
Grime, J.P. 1979. Plant strategies and vegetation processes. Wiley, Chichester, $371 \mathrm{pp}$.

Grime, J.P. 2001. Plant strategies, vegetation processes, and ecosystem properties, 2nd edn. Wiley, Chichester, 417 pp.

Grubb, P.J. 1986. Problems posed by sparse and patchily distributed species in species-rich plant communities. In: Community eco$\log y$ (J.M. Diamond \& T.J. Case, eds.), p. 207-225, Harper \& Row, New York.

Jutila, H.M. 1997. Vascular plant species richness in grazed and ungrazed coastal meadows, SW Finland. Annales Botanici Fennici 34: 245-263.

Keeley, J.E. \& C.J. Fotheringham 2003. Species-area relationships in Mediterranean-climate plant communities. Journal of Biogeography 30: 1629-1657.

Laanisto, L., J.F. Fernandez-Palacios, R. Otto, M. Zobel \& M. Pärtel 2008. The balance between speciation and dispersal in forming local species pools: an example from the Canary Islands. In: Frontiers of vegetation science - an evolutionary angle (L. Mucina et al., eds.), p. 94. Keith Phillips Images, Somerset West.

MacArthur, R.H. \& E.O. Wilson 1967. The theory of island biogeography. Princeton Univ. Press, Princeton, 203 pp.

Merunková, K., Z. Preislerová, M. Chytrý 2012. White Carpathian grasslands: can local ecological factors explain their extraordinary species richness? Preslia $84:$ 311-325.

Miles, J. 1979. Vegetation dynamics. Chapman \& Hall, London, 80 pp.

Onipchenko, V.G., A.F. Mark \& G. Wells 2005. Floristic richness of three perhumid New Zealand alpine plant communities in comparison with other regions. Austral Ecology 30: 518-525.

Onipchenko, V.G. \& V.N. Pavlov 2009. Local plant species richness depends on the total area of alpine communities. Doklady Biological Sciences 427: 381-383.

Onipchenko, V.G. \& G.V. Semenova 1995. Comparative analysis of the floristic richness of alpine communities in the Caucasus and the Central Alps. Journal of Vegetation Science 6: 299-304.

Ouborg, N.J. 1993. Isolation, population size and extinction: the classical and metapopulation approaches applied to vascular plants along the Dutch Rhine-system. Oikos 66: 298-308.

Pärtel, M., R. Mandla \& M. Zobel 1999. Landscape history of a calcareous (alvar) grassland in Hanila, western Estonia, during the last three hundred years. Landscape Ecology 14: 187-196.

Peel, M.C., B.L.Finlayson \& T.A.McMahon 2007. Updated world map of the Köppen-Geiger climate classification. Hydrology and Earth System Sciences 11: 1633-1644.

Schwinning, S. \& J. Weiner 1998. Mechanisms determing the degree of size asymmetry in competition among plants. Oecologia 113: 447-455.
Sedelnikov, V.P. 1979. Flora and vegetation of Ku₹netskii Alatau bigh mountains. Nauka, Novosibirsk, 168 pp. (in Russian) [Силельников В.П. 1979. ФАора и растительность высокогорий Кузнецкого Алатау. Новосиборск: Наука. 168 с.]

Shmida, A. \& S. Ellner 1984. Coexistence of plant species with similar niches. Vegetatio 58: 29-55.

Shlotgauer, C.D. 1990. Plant cover of suboceanic bigh mountains. Nauka, Moscow, 224 p. (in Russian) ШАоттауер C.А. 1990. Pacтительный покров субокеанических высокогорий. Москва: Наука. 224 с.]

Tang, C.Q., M. Ohsawa, M.J.A. Werger \& Y.C. Yang 2013. Endemism in mainland regions - Habitats of Tertiary relict trees in China. In: Endemism in vascular plants (Plant and Vegetation V. 9) (C. Hobohm, ed), p. 287-305. Springer, Heidelberg.

Tilman, D. 1986. Evolution and differentiation in terrestrial plant communities: the importance of the soil resource:light gradient. In: Community Ecology (J. Diamond \& T.J. Case, eds), p. 359-380. Harper \& Row, New York.

Tsuyuzaki, S., S. Urano \& T. Tsujii 1990. Vegetation of alpine marshland and its neighboring areas, northern part of Sichuan Province, China. Vegetatio 88: 79-86.

Whithemore, T.C., R. Peralta \& K. Brown 1985. Total species count in a Costa Rican tropical rain forest. Journal of Tropical Ecology 1: 375-378.

Willems, J.H. 1983. Species composition and above-ground biomass in chalk grassland with different management. Vegetatio 52: 171-180.

Wilson, J.B., R. Peet, J. Dengler \& M. Pärtel 2012. Plant species richness: the world records. Journal of Vegetation Science 23: 796-802.

Wilson, J.B. \& M.T. Sykes 1988. Some tests for niche limitation by examination of species diversity in the Dunedin area, New Zealand. New Zealand Journal of Botany 26: 237-244.

Yan, W. \& V.G. Onipchenko 2006. Relation of the snow cover to the structure of vegatation in the alpine communities of the eastern Tsinghai-Tibetan Plateau. Zhurnal Obshchei Biologii 67: 452-463 (in Russian with English summary) [Янь У, Онипченко В.Г. 2006. Связь снежного покрова со структурой растительности в высокогорьях востока Цинхай-Тибетского нагорья // Журнал общей биологии. Т. 67, № 6. С. 452-463.]

Zobel, M. 1992. Plant species coexistence - the role of historical, evolutionary and ecological factors. Oikos 65: 314-320. 